\title{
Country of origin as a food choice evaluation criterion
}

\author{
Mohammed ABDALRAHMAN \\ Szent Istvan University, Gödöllö-Hungary. E-mail: mohd.salem82@gmail.com
}

Keywords: country of origin, COO, food buying decision, food choice,

\section{Research problem}

Consumers around the world facing a problem of taking the best buying choice especially when their decision is related to buying food products. However, when consumers confronted with a choice set of offered options, consumers' perceived relative value of the options is the main determinant of their choice. Still, consumers are not motivated all of the time or able to evaluate the available options before making choices and search for some clues in the product that can help them to take a fast and good buying decision. Therefore, this study aims to highlight the effect of country of origin as a food choice evaluation criterion on consumer choice of their food products.

\section{Methodology}

To achieve the study objectives a desk research was conducted by viewing different articles and previous studies that published in different databases like EBSCO, Scopus, Web of Since and others. After viewing the previous studies, a summary of the main concepts will be generated. However, this is an initial study that will be followed by other survey studies that will collect and analyze primary data for better understanding the effect of country of origin on consumer food choice.

\section{Results and discussion}

Su and Canavari (2018) supposed that the country of origin of food product represents its "nationality" and it is comparable to a "brand" that may be designed with a national flag. However, different studies supported that the country of origin (COO) affects consumers' food choices in different food sectors (Pedersen et al., 2018, Thøgersen et al., 2019, Aichner, 2016) and that customers evaluate food products quality according to their COO and that they are more willing to buy food products produced in some countries than in others (Thøgersen et al., 2019). Moreover, most of the consumers have a general belief that imported food brands have lower quality standards in comparison to domestic food brands, therefore, they prefer to choose local food brands and avoid as possible to buy imported food brands. (Schjøll, 2017). Also, customers believe that country of origin (COO) is linked to quality(Allman et al., 2016) in the same way as the brand name, the price, and various product labels (Thøgersen et al., 2019, Allman et al., 2016)

Consumers associate different factors to countries as the country image, consumer ethnocentrism, geographical distance, cultural distance, and trust in products from the different countries, these factors influencing how the customer will perceive the relative level of quality of each country products (Thøgersen et al., 2019). However, one of the most researched country image factors is economic development. Where consumers prefer products from a more developed country to products from a less developed country (Thøgersen et al., 2019, Uyar, 2018). 
Structural trade barriers between countries had been reduced during the past decades, therefore, many countries have strengthened preference barriers by implementing mandatory country of origin labeling for most types of food products(Su and Canavari, 2018, Schjøll, 2017). This allows consumers to rely on products origin to make more effective buying decision (Schjøll, 2017). On the other hand, food producers can use different strategies to communicate their product's country of origin to their target markets, these strategies range from unregulated COO strategies as using flags, symbols, typical landscapes or buildings on packaging and in advertisement, to legally regulated strategies like the communication of a 'Made in' statement or geographically based quality labels like the European Union's Protected Designation of Origin (PDO) indication (Pedersen et al., 2018).

\section{Conclusion}

As a result of reducing the entry barriers to international markets, food producers should pay more attention to the area of the country of origin of their products and understanding how local and international consumers perceive and evaluate their COO image. Thus, companies should use different promotional tools to promote their country of origin in both of domestic and foreign markets since this can highly influence consumers attitudes and preferences toward the company brands through giving a clue about the brand performance. As a consequence of affecting the consumer's preferences and perception, their intention to buy can also be affected

\section{References}

Aichner, T. F., Cipriano; Trentin, A. (2016): The country-of-origin lie: impact of foreign branding on customers' willingness to buy and willingness to pay when the product's actual origin is disclosed. The International Review of Retail, Distribution and Consumer Research, 27, 43-60. https://doi.org/10.1080/09593969.2016 .1211028

Allman, H. F., Fenik, A. P., Hewett, K. \& Morgan, F. N. (2016): Brand Image Evaluations: The Interactive Roles of Country of Manufacture, Brand Concept, and Vertical Line Extension Type. Journal of International Marketing, 24, 40-61. https://doi.org/10.1509/jim.15.0055

Pedersen, S., Aschemann-Witzel, J., Thøgersen, J. (2018): Consumers' evaluation of imported organic food products: The role of geographical distance. Appetite, 130, 134-145. https://doi.org/10.1016/j. appet.2018.08.016

Schjøll, A. (2017): Country-of-origin preferences for organic food. Organic agriculture, v. 7, pp. 315-327-2017 v.7 no.3. https://doi.org/10.1007/s13165-016-0159-1

Su, j. Y. \& Canavari, M. (2018): Delphi study on country-of-origin labelling for processed foods. Agricultural and Food Economics, 6. https://doi.org/10.1186/s40100-018-0103-7

Thøgersen, J., Pedersen, S. Aschemann-Witzel, J. (2019): The impact of organic certification and country of origin on consumer food choice in developed and emerging economies. Food Quality and Preference, 72, 10-30. https://doi.org/10.1016/j.foodqual.2018.09.003

Uyar, A. (2018): A Study on Consumers' Perception About Chinese Products and Their Willingness to buy. International Journal of Eurasia Social Sciences, 9, 1121-1143. 